\title{
SECURITY CO-OPERATION IN THE SOUTHERN AFRICAN DEVELOPMENT COMMUNITY: INSIGHTS FROM THE NEW INSTITUTIONALISM ${ }^{1}$
}

\author{
Dr Anthoni van Nieuwkerk \\ Centre for Defence and Security Management \\ University of the Witwatersrand
}

...Summit congratulated the Outgoing Chairperson for his untiring efforts to improve the performance of the Organisation and for steering it to greater heights in its integration agenda during his tenure of office

SADC Communiqué, August 2006

...the AU, Nepad, Ecowas, SADC... are more like per diem watering holes than competent agencies

Van Zyl Slabbert, The other side of history, 2006

It is the capacity for solidarity in the face of adversity that gives the SADC region a unique ability to remain cohesive

Fisher and Ngoma, The SADC Organ, 2005

\section{Introduction}

This article focuses on the institutional dimensions of security cooperation as it manifests in the Southern African Development Community (SADC). ${ }^{2}$ As the quotations above suggest, security co-operation, as part of a bigger project of regional integration, is not obvious. Indeed, should southern Africans believe their politicians when the latter claim that SADC is 'forging ahead' on the road to formal integration? Slabbert is not convinced. Not only academics, but civil society increasingly question its raison d' etre. For many, it is unclear whether or how SADC provides human security to the people of the region. Instead, SADC members' positions on the key regional challenges (trade, growth and development, security and stability) are driven by national interest rather than regional interest - as realists argue, national interests (a must-have) are hard and measurable; regional cooperation (often a nice-to-have) is hard to measure. Or should we accept a regional consciousness shaped by a shared historical experience - a problematic assumption? 
Few ordinary southern Africans can identify with rulers and bureaucrats who romantisise the past, fear the future, and suffer from policy implementation paralysis. Increasingly, a new generation of southern African citizens are growing up with no direct experience of apartheid and colonialism. Their sense of belonging is shaped by other factors: securing a job, accessing anti-retroviral medication, craving a Nokia (or all three). A policy analysis whereby one looks at organisational behaviour through the lenses of new institutionalism might enable a deeper understanding of SADC security co-operation. However, as any reflective postmodern audience would know, social theory, especially in the interorganisational or institutional domain, often obscures more than it reveals. March and Olson once remarked, "what we observe in the world is inconsistent with the ways in which contemporary theories ask us to talk" (quoted by Powell and DiMaggio, 1991: 3). With these caveats in place, the article commences.

\section{New Institutionalism}

For a long time, institutions were at the heart of political science and public administration. More recently, researchers have expressed a renewed interest in institutions, but going beyond constitutions, legislatures and executives by focusing on processes, actors, interests, norms and rules (Parsons, 1995: 223). This article use institutions to refer to forms of social organisation, specific or abstract (Williams, 1983: 169). Following Lowndes (1996), institutions display the following characteristics:

- Institution is a middle-level concept. Institutions are devised by individuals, but in turn constrain their action. They are part of the broad social fabric, but also the medium through which day-to-day decisions and actions are taken.

- Institutions have formal and informal aspects. Institutions involve formal rules or laws, but also informal norms and customs - 'the way things are done'.

- Institutions have legitimacy and show stability over time. Institutions have legitimacy beyond the preferences of individual actors.

However it must also be said, rather hastily, that new institutionalism is not a single or coherent body of theory. The concept is used in many different disciplinary contexts - political studies, policy studies, economics, or organisational theory (for discussion, see Lowndes, 1996; Powell and DiMaggio, 1991). Some of these uses will be discussed later on in the paper. The valuable point most new institutionalist perspectives make is that institutions are not things but processes. How is this relevant to SADC and its efforts at security co-operation? This article explores two avenues.

It is worth re-emphasising that institutions display three key characteristics: a set of formal and informal rules which structure social action; change and stability which are stages in an institutional life cycle; and strategic 
action which plays an important role in driving change, whilst norm-driven behaviour is key to sustaining institutional rules over time. On the basis of these variables Lowndes (1996: 184-197) constructed six short 'vignettes' or sketches of institutions, four of whom are further summarised below.

\section{Box 1: Institutional behaviour: New institutional insights}

\section{The 'stable' institution}

Institutions reduce uncertainty by providing a stable, but not necessarily efficient, framework for human interaction. Technically inefficient institutions persist because they contribute to stability and harmony in interaction and because they are deeply embedded in culture and tradition. It is the tenacity of informal constraints that produces institutional stability. While formal rules (constitutions, contracts, standing orders) can be redrawn overnight, informal rules change slowly - 'old' conventions often persist in the face of new formal codes.

\section{The 'manipulated' institution}

Public choice scholars view institutions as obstacles to effective exchange. They predict processes of 'institutional entropy' in the political arena. Manipulated by utility-maximising politicians and bureaucrats, institutions degenerate over time; they come to serve the individual, private interests of officials and any conception of the public interest is lost.

\section{The 'disaggregated' institution}

The 'policy community' or 'policy network' approach paints a picture of institutions which are disaggregated, informal, policy-specific and relatively stable over time. Policy is made not by a unified machine but by an assortment of actors linked together in networks. Networks have a limited number of participants who interact frequently, share values and exchange resources. There are low levels of conflict and 'positive-sum' power games. However the specific pattern of network relationships varies in different policy fields: there are also areas in which interagency relationships are not institutionalised as networks; such fields are characterised by a lack of stability and continuity.

\section{The 'appropriate' institution}

Institutions provide order in political life. They express norms of decision-making and behaviour, providing a 'logic of appropriateness'. Seemingly neutral procedures and structures embody particular values, norms, interests, identities and beliefs. A calculus of identity and appropriateness is more important to actors than a calculus of political costs and benefits. Rules are sustained by trust, and reflect and embody historical experience. Institutions generally change in an incremental way through responding to environmental signals.

Source: Lowndes, 1996

Another version of the new institutionalism (Smith, 1994: 8-12) holds that through the process of institutionalisation, relations among states in a co-operative 
arrangement (such as the European Union, which he examined) progress from narrow instrumental rationality (characterised by intergovernmentalism) to a more collective or social rationality (characterised by legitimate procedures of governance and corresponding changes in their domestic policies). One can distinguish between the following stages or steps in such a process (wisely allowing for overlap and inconsistency), and it is repeated here with a view to its applicability to the SADC arena:

Establishment of the policy domain as an intergovernmental forum. The start is often a conscious, public decision amongst a number of actors to organise their co-operation in an issue-area. In the case of southern Africa, the Frontline States (FLS) historically played this role, although it must be acknowledged that the FLS itself was a product of the Pan African Freedom Movement for East and Central Africa (PAFMECA), later changed to include the southern African nationalist movements seeking independence (Omari, 2000: 198).

Information sharing. Once actors have agreed to co-operate, they may then begin a discourse about the means and ends of their co-operation. This can initially be mere discussion about policy co-ordination ('cheap talk') or specific cooperative policy actions ('results'). As goal-oriented communication intensifies, the demand for greater structure grows and co-operation becomes more likely. Arguably, the Defence Staff Committee (DSC, later renamed the Inter-State Defence and Security Committee (ISDSC)) as a mechanism of the FLS played this role.

Norm creation and codification. Once communication moves beyond 'cheap talk', institutionalisation takes on a new dynamic, involving the generation of norms. As officials learn to trust each other and develop a shared understanding of what their co-operation actually involves, it becomes possible for them to establish clearer obligations regarding ends and means of a specific policy domain. Smith examined various types of norms: informal customs, or the traditions and practices that emerge in day-to-day interactions among officials, norms that are codified into written norms, a further transition of norms to rules as specific rights and obligations applicable to certain situations, and finally the transition from rules into formal laws. Again, arguably, the Southern African Development Co-ordinating Conference (SADCC) started to play this role from 1980 (Mandaza and Tostensen, 1994).

Organisations. Behavioural norms are not the only manifestation of institutionalisation. The establishment of a permanent organisation to administer some policy domain represents an additional degree of institutionalisation. Such formal organisations can change the nature of co-operation. At the very least, organisations can provide some institutional memory concerning previous decisions. At the most, the organisation itself can become an autonomous actor with policy influence. In the case of southern Africa, the establishment of SADC in 1992 indicated that the region was moving up a level in terms of institutionalised political and economic co-operation (Le Pere and Tjønneland, 2005). 
Smith finally identifies governance as a further evolution of co-operation, where states consider co-operation as a unified whole. This in his opinion requires a policy process whereby governance is seen as the authority to make, implement, and enforce rules in a specific domain.

The above process can be displayed in the following format:

Box 2: Institutionalisation of security co-operation in southern Africa

\begin{tabular}{|l|l|}
\hline Process & Application \\
\hline $\begin{array}{l}\text { 1. Establishment of a policy } \\
\text { domain as an intergovernmental } \\
\text { forum }\end{array}$ & $\begin{array}{l}\text { PAFMECA / PAFMECSA / FLS } \\
\text { Alliance }\end{array}$ \\
\hline 2. Information sharing & DSC / ISDSC \\
\hline 3. Norm creation and codification & SADCC \\
\hline 4. Organisation & SADC \\
\hline 5. Governance & $?$ \\
\hline
\end{tabular}

\section{Analysis}

This process has seemingly allowed for informal patterns of security cooperation in southern Africa (primarily focused on the struggles against colonialism and apartheid) to be formalised (that is, rules-driven and forward-looking) with the establishment of organisational structures. Whether the restructured SADC of 2001 and its Organ on Politics, Defence and Security Co-operation (OPDSC) and the range of recently-adopted policy frameworks in the area of security co-operation (including the 2001 protocol on politics, defence and security co-operation, the Mutual Defence Pact and the Strategic Indicative Plan for the Organ (SIPO)) can be seen as approaching the fifth level of institutional co-operation (governance) is a question to be examined. The other side of the same coin can be stated thus: to what extent are SADC member states willing and able to harmonise national decision making (structures and practices) in order to enhance the region's security authority to make, implement and enforce rules? The second question is to what extent SADC displays institutional behaviour of a 'stable', 'appropriate', 'manipulated' or 'disaggregated' kind. In a recent seminal analysis of SADC, Oosthuizen (2006: 325) concludes that it provides an "evolving, institutionalised, rules-based forum within which the members meet regularly to discuss and argue about political and security issues" - a strong vote in favour of seeing SADC as having evolved governance capabilities, or displaying 'appropriate' behaviour. 
However, participant observation (of discussions - formal and informal between SADC members and them and the donor community) suggests that three alternative scenarios are possible, whereby SADC follows -

- an holistic (integrated and comprehensive) approach to trade, economic and security integration, accompanied by a negotiated road-map with clear time lines and implementation indicators, therefore approaching governance or appropriateness;

- a dual-speed approach to integration: fast-tracking trade and economic integration, but slow security integration, accompanied by separate RISDP and SIPO implementation plans, therefore displaying organisational or disaggregated behaviour;

- a radical rethink of the nature of the relationships between countries in southern Africa, therefore suggesting mere information sharing behaviour and signs of being manipulated.

The article now focuses on SADC's genesis, evolution and current state of implementation of rules in the area of security co-operation in order to further interpret its institutional nature and behaviour.

\section{SADC's genesis}

Formal, inter-state co-operation in southern Africa is a relatively new phenomenon. The roots of this practice lie in the region's complex colonial past, whereby European powers maintained an exploitative presence in the region primarily for economic purposes. Wars of liberation gave rise to security cooperation (via PAFMECA, PAFMECSA and especially the Frontline States (FLS) alliance, formed in the 1970s) and economic co-operation (via the SADCC established in 1980). Largely in preparation for a liberated South Africa, the region reconfigured its co-operative strategies by establishing SADC in 1992. As it grew in membership (from nine to fourteen) and objectives (from socio-economic cooperation to integration), SADC's structure and operations had to be refined. This was initiated in 1999 and concluded in 2001. It also formalised peace and security co-operation by establishing a comprehensive decision making architecture. In 2003, it adopted an implementation plan.

\section{The nature of the integration project}

SADC is first and foremost an arrangement facilitating economic integration in order to "improve the quality of life of the peoples of the region" (SADC, 1992). SADC's genesis reflects this priority. When the (former) SADCC was formed in 1980, it adopted the slogan 'Southern Africa - towards economic liberation'. The current (1992+) SADC vision is one of 
...a common future, a future within a regional community that will ensure economic well-being, improvement of the standards of living and quality of life, freedom and social justice and peace and security for the peoples of Southern Africa.

However, as the academic literature on regionalism and human security makes clear, this is a task not easily achieved, requiring a range of objective and subjective preconditions. ${ }^{3}$ Indeed, at the time when the SADC leadership was contemplating the future management of power relations, a throng of policy analysts recommended the need for SADC to adopt the 'new', widened definition of security (for an overview of these debates, see Zacarias, 2003). The uncritical assumption was that this would lead to "the elimination of war" (a phrase coined by Deutsch) and sustainable human development - features of a 'security community' (Booth and Vale, 1995: 285). Much was to be said for being inspired by the mood of the time - the dawn of a new post-Cold War, post-apartheid era - and the caution from some analysts (and policy makers), namely not to underplay the impact of the violent political history of the region. ${ }^{4}$

And indeed, for analysts and policy makers alike, a regional grouping such as SADC was hoped to evolve into a 'secure community' on the basis of exhibiting four conditions: active engagement with security and development challenges, a timeline for achieving objectives, an inclusive process, allowing for state and civil society input, and institutionalisation of the process (Schoeman, 1998: 1). However, the model never fully accounted for the long term impact of the historical experiences of the region, and with the onset of the wave of democratisation in southern Africa some of these faultlines rose to the surface. Indeed, the eruption of the Great Lakes crisis vaporised the naïve beliefs of many of the theoretical community builders. In 1999, one assessment was that SADC appeared unable to meet the first three conditions, and partially met the test of institutionalisation (Van Nieuwkerk, 1999: 1-3. See also Isaksen and Tjønneland, 2001: 60; Nathan, 2004: 13. See Ngoma, 2005, chapter 1, for an optimistic view.) A few years later Landsberg and Baregu concluded that SADC's security architecture remained 'elusive', operationalisation of the OPDSC was not guaranteed, and that the gap between policy and practice needed to be closed (Landsberg and Baregu, 2003: 15). Tjønneland (2005) came to similar conclusions in a thorough overview of the SADC security system.

Several years later, we still argue that the SADC project can progress but only on the basis of careful phased planning towards meeting these four conditions. And institutional development is still a key requirement. On this issue, Hansohm (2005: 213) observed:

The formation of a regional integration arrangement requires that regional institutions be developed to which important facets of national economic and political decision making will be subordinate. Its successful establishment... requires a major transition, which can easily trip 
participating countries up. This may explain why the conclusion of regional integration arrangements is not matched by the active participation of member states in the integration exercises...

This paper argues that the deepening of regional co-operation in the area of peace and security similarly requires institutional governance in the sense that regional institutions be developed to which important facets of national (economic and political) decision making will be subordinate (see also Mulaudzi, 2006). Of course, this is not the only way in which countries have to pursue security cooperation: alternative avenues include 'functional co-ordination' (to deal with, say, cross-border theft), or coalition or alliance formation (similar to networking whereby a number of countries come together for a short period of time to pursue policy objectives in a specific issue-area). But the language of the SADC Treaty and the OPDSC protocol is clearly written with more in mind! Hence the seemingly useful fit between new institutionalism and SADC's behaviour. The question then becomes, can SADC make the transition to institutional governance as specified above?

Although one can track institutional development (e.g. OPDSC Protocol, adopted in 2001) such developments seem not to be matched by the active participation of members, to the extent that one can discern a positive impact of such institutional activity upon regional peace and security. If the SIPO (adopted in 2003) was designed to give effect to the mandate of the OPDSC (as well as a measuring tool for the Organ's impact) then the evidence is not entirely convincing. The sections below will interrogate these impressions in more detail.

\section{Institutional evolution}

Regional co-operation in the $1980 \mathrm{~s}$, even if informal and limited, succeeded in realising a number of regional development projects, mainly in the infrastructure and food security sectors (Lambrechts, 2001: 4-9). The activities of the Frontline States alliance, in its quest to eradicate colonial rule and apartheid in southern Africa, additionally brought about a sense of regional identity and briefly promoted a shared political vision (Omari, 2000: 18). The SADCC was transformed into SADC in 1992, reflecting the changing regional - and external - environments. Most importantly, South Africa joined SADC in 1994, as did the Democratic Republic of Congo (DRC) in 1997. However, a year later a major regional war erupted, involving the DRC and a number of other SADC member states. At the same time an attempted coup destabilised the small country of Lesotho. SADC's unresolved security structures (the Organ chaired by President Robert Mugabe) played a controversial role in the attempt to resolve these crises (Williams, 2001). In following the logic of 'no development without stability' broad institutional refinement was therefore called for. As Tjønneland (2005: 168) notes, in March 2001, an extraordinary SADC Summit approved the proposed recommendations for far-reaching changes in SADC's institutional framework and the structure for executing its 1992 mandate. These included changes in SADC's governing 
structures at the regional and national level, but most importantly a plan for the centralisation of the 21 sector co-ordinating units and commissions located in 12 of its member countries. These units were brought together in four clusters in a strengthened SADC Secretariat in Gaborone.

At the Council of Ministers Meeting and Summit in Blantyre in August 2001 these changes in SADC structures were further consolidated. The SADC Treaty was amended to take into account these institutional changes. In addition the Summit signed a Protocol on Politics, Defence and Security Co-operation which provided for an Organ on Politics, Defence and Security Co-operation under the SADC Summit (from here on the Organ). The Organ has its own set of regional structures and mechanisms for policy formulation and implementation.

The Summit is the supreme policy-making institution of SADC. It is led by a Troika system consisting of the Chairperson, Incoming Chairperson and the Outgoing Chairperson. It meets twice a year: first, before 31 March each year to focus primarily on regional economic development matters and the SADC Programme of Action. The second takes place in August/September and is dedicated to political matters. Decisions are taken by consensus and are binding.

The Organ also operates on a Troika basis. The Troika members are selected by the Summit from among the members of the Summit except that the Chairperson of the Organ Troika cannot at the same time have the Chair of the Summit (neither can a member simultaneously belong to both Troikas). Under the Organ a Ministerial Committee (MCO) was established consisting of the Ministers responsible for foreign affairs, defence, public security and state security.

The SADC Summit in Blantyre also adopted the long-awaited Protocol on Politics, Defence and Security Co-operation. In 1996 SADC decided to create an Organ on Politics, Defence and Security. As noted above, it was never properly structured and a variety of problems erupted. The chairing of the Organ, the permanency of that position and its status vis-à-vis SADC became hotly contested issues. At the Blantyre Summit, and after intense negotiations and pressure, it was decided to bring the Organ firmly under SADC control.

The Protocol also provides for an elaborate structure of the Organ. Under the Chair and the Troika there is a Ministerial Committee comprised of the SADC ministers responsible for foreign affairs, defence, public security and state security. It operates much like the SADC Council of Ministers and has a partly overlapping membership.

The Inter-State Politics and Diplomacy Committee (ISPDC) comprises the ministers responsible for foreign affairs. It shall perform such functions as may be necessary to achieve the objectives of the Organ relating to politics and diplomacy. It may establish such substructure as it deems necessary. 
The Inter-State Defence and Security Committee (ISDSC) comprises ministers responsible for defence, public security and state security. It is an established committee formed more than 20 years ago by the Frontline States (it started off as the Defence Staff Committee, and became the ISDSC when South Africa, Malawi, Swaziland and Lesotho joined after 1994). It has a fairly elaborate substructure, especially under the Defence subcommittee and a range of sub-sub committees on functional areas of co-operation. Under the public security subcommittee there is the Southern African Regional Police Chiefs Co-ordination Committee (SARPCCO) which has a permanent secretariat hosted by the Secretariat of the Interpol Sub-Regional Bureau for Southern Africa located in Harare. The ISDSC itself has never had a permanent secretariat. These services are provided by the ISDSC Chair on a rotational basis.

The Organ is supposed to be supported by the Directorate for Politics, Defence and Security Affairs based at the SADC Secretariat in Gaborone. It functions under the overall supervision of the SADC Executive Secretary and is headed by a Director for Politics, Defence and Security. The Directorate's tasks, as interpreted by its Director, relates to politics, defence and security issues as defined in the Treaty, Protocol and the SIPO (focusing primarily on strategic planning and policy analysis and development); the monitoring and evaluation of the implementation of Organ decisions; and the provision of administrative backup to the Organ. It also supervises the activities of the SADC Regional Peacekeeping Training Centre (RPTC) based in Harare (Ndlovu, 2006: 4).

The current structural refinement of the Organ relates to the establishment of a SADC Brigade (also known as the SADCBRIG) as part of the African Standby Force (ASF) concept. ${ }^{5}$ According to Macaringue's interpretation (2006: 2), the 2001 SADC Protocol on the OPDSC and the Mutual Defence Pact are the foundation and core internal legal basis for the creation of a military capability by SADC. The SADC Organ and its Troika provide the guidance and symbolise the political will to implement the $\mathrm{AU}$ prescriptions for the establishment of Regional Brigades as components of the ASF. He captures the purpose of this structural refinement as follows: "The SADC vision is that the ultimate goal of the OPDSC and the Mutual Defence Pact is that peace, stability, and development would be protected, and that when necessary, military force would be deployed to enforce peace" (Macaringue, 2006: 2; emphasis added). AU thinking is slightly broader, to encompass the idea of deployment in support of peace missions (including peace building), preventive deployment, intervention to restore peace and humanitarian assistance. ${ }^{6}$ 


\section{SADC's SIPO}

The Foreword to the printed version of the SIPO (dated August 2004) states that the SADC Protocol on Politics, Defence and Security Co-operation is intended to serve as an instrument for dealing with the region's political and security challenges, and that the SIPO was formulated to assist with the implementation of the Protocol:

The SIPO is not an end in itself... it is an enabling instrument for the implementation of the SADC developmental agenda (embodied in RISDP). The core objective of the SIPO therefore, is to create a peaceful environment... to realise the region's socio-economic objectives.

The SIPO was designed to do three things: provide guidelines for action (strategies and activities); shape the institutional framework for the day to day activities of the Organ (including the Protocol and the Mutual Defence Pact); and align the regional peace and security agenda with that of the African Union (in particular the Standby Force and aspects of good governance). ${ }^{7}$

There seems to be a variety of reasons for the production of an implementation plan which contains over 130 objectives with no clear hierarchy, and no serious effort to produce a business plan for the operationalisation of the Organ. ${ }^{8}$ First of all, the manner in which the document evolved is important for understanding its shape. SADC's preference for consensual policy-making resulted in a number of countries adding their voices to the activities of the working group which was set up to construct the guideline in the first place. The resultant document reflects more accurately the combined national interests of fourteen countries instead of a strategic management tool to guide Organ activities. As such it reminds us of the delicate nature of security perspectives and preferences amongst members of SADC.

Secondly, the management of the Organ's affairs takes place in the context of a small (and weak) administrative infrastructure and capacity. This has obvious implications for SADC's ability to prioritise, implement, monitor and evaluate mechanisms and plans relating to its peace and security agenda. The choice to run a 'minimalist' Organ Directorate relates to divergent political outlooks and priorities of its member states whereby some governments are preoccupied by state (or regime) security issues, while others emphasise human security. As some analysts provocatively argue, the Organ was created to ensure the self-preservation of SADC and its 'governing elites' (Makoa, 2005: 124; Van Zyl Slabbert, 2006: 67). Governments have also adopted different approaches to dealing with internal challenges, reflecting the region's varied experiences with democratisation (Nathan, 2004; Tjønneland, 2005).

It would therefore be misleading to expect the SADC Secretariat to be engaged in political decision making relating to regional peace and security: it exists 
by design of the member states, in order to carry out political instructions. Put differently, the SADC Treaty and the mandates of the Secretariat and Directorate restrict it to being an administrative (or implementation, monitoring and evaluation) unit with no political decision-making powers. SADC member countries have not (yet) chosen to establish a regional institution with supra-national power in the areas of defence and security - critically, a precondition for moving the institution towards a security community. Given these strictures, the relationship between the Secretariat and individual members becomes key, as does leadership. In short, the Organ is not more than the sum of its parts, and given its in-built shortcomings, the parts become key. What is it that the participating member countries want from the SADC security agenda? Although attempted before (Cawthra and Van Nieuwkerk, 2004), this question remains difficult to answer without additional research into the national security agendas of SADC member states.

\section{Status of implementation}

The rather exhaustive list of objectives, strategies and activities contained in the SIPO document can be summarised to include democracy building, peacekeeping training, police co-operation especially regarding cross-border crime, disaster management, conflict management (with the emphasis on conflict resolution), and food security. In the (much) longer term the organisation plans to promote institution-building, peace enforcement and harmonisation of foreign policies. But where is the current focus?

Some analysts believe the focus to be wrong altogether. For example, Makoa (2005: 115-119) has serious reservations about the ability of the Organ to act as an integrative, democratic force in the region and points to its "inability' to deal with political crises in Angola, Zimbabwe, Swaziland and the DRC" (see also Nathan, 2004). This, in his view, demonstrates its lack of credibility and legitimacy ('protecting governments rather than people'), leading to his call for the Organ to realise its potential by being democratised, that is, opened up to the people, presumably via introducing parliamentary oversight over the institution. This debate, of course, raises questions about the nature of the integration project (scenario 2, as discussed) which lies beyond the scope of this paper. It is also necessary to point out that the Organ's so-called 'inability' to deal with political crises seems to be a misreading of the nature of SADC decision-making: it chose to deal with political crises in a certain manner (for an example see Ndlovu's account of SADC and Zimbabwe, below).

If one believes the Organ to be of value in the broader integration process, then one can focus on an analysis of its implementation. Tjønneland (2005: 177) sees three emerging priority areas: small arms, elections management and peace support efforts. On the first issue, he notes that SARPCCO seems to be making more progress than the Organ Secretariat itself (although it must be noted that the former is not formally part of the latter). Regarding peace support operations, he notes progress but also the emergence of various problems: the failure to get the 
RPTC in Harare operational, the absence of a mandate for SADCBRIG deployment, the question of the financing of a deployment mission, and finally, contrary to UN doctrine, the absence of any meaningful civilian involvement in the activities of the standby force. Again, it must be noted that the putative SADCBRIG can only be understood from the perspective of the AU's continental security architecture and plans (Van Nieuwkerk, 2003: 55).

It is useful to probe the thinking of the Organ's Directorate on these matters. In a recent review of the status of the SIPO the acting Director of Politics, Defence and Security argued that one had to understand the SADC project from the perspective of its member states' historical frame of mind, meaning -

...the wounds and scars inflicted by the forces of colonialism and oppression continue to serve as a fundamental reference that draws the SADC citizenry together around a paradigm of political cautiousness and pragmatism... insecurity and destablisation of a neighbour is one's own destabilisation, and therefore must be faced collectively (Ndlovu, 2006: 4).

The acting Director then noted that SADC's foreign policy had three main objectives: market access, consolidation of democracy, and security. In light of this, recent Organ activities included "...conflict resolution interventions in Lesotho, monitoring political developments in Zimbabwe to ensure that only peaceful means are used in addressing issues of national interest, electoral observations in member countries, and peace building in Angola and the DRC". All of this meant that "...there is no dispute that SADC is relatively the most peaceful region in Africa with an undisputed emerging market" (Ndlovu, 2006: 6).

He also addressed the question of the relationship between the SIPO and SADC's Regional Indicative Strategic Development Plan (RISDP) by pointing out that "[a]s we gear ourselves for a full implementation of the RISDP, the operationalisation of the SIPO becomes urgent lest the RISDP is compromised by insecurity and political instability" (Ndlovu, 2006:7). The thrust of his subsequent argument was that of human security. As he argued, democracy, good governance and human rights were interrelated, and despite gains with democratisation (such as mainstreaming human rights in the region's political framework) the region faced a number of socio-economic challenges that posed as threats to human security. These included inadequate shelter and education, unemployment, poverty and scarce resources, food insecurity, health care and HIV/Aids, and post-conflict population displacement situations. In his view, the SIPO was an operational vehicle "which can be enhanced and utilised to respond to these threats" (Ndlovu, 2006: 8). He identified three areas amenable for partnerships with donors (now called International Co-operating Partners or ICPs): post-conflict peace building and reconstruction (with a focus on small arms and light weapons (SALW), mine clearance, demobilisation of former combatants (DDR), and the need to structure domestic SADC/Civil Society Partnerships), capacity building relating to Electoral Management Bodies, and a 'smart partnership' to democratise and strengthen 
multilateral institutions such as the UN Security Council and the Bretton Wood Institutions. ICP support for SADCBRIG and the RPTC was identified separately in his overview.

On the question of security challenges, the acting Director identified terrorism and mercenarism as issues needing urgent intervention. In his view the recent Aswat case ${ }^{9}$ illustrated that the region could be perceived as a safe haven for terrorists, and moreover, the region needed a strong regional policy against mercenarism, lest the perception be created that it was a mercenary brewing zone. He also identified the operationalisation of a regional early warning centre (REWC) as important. In order to prevent and manage conflict, the REWC would monitor threats and risks such as terrorism, mercenarism, drug trafficking, famine and potential natural and human induced disasters, by conducting research, presenting its findings and making recommendations for policy intervention. He added that the REWC would be based on open sources and work with civil society. Mediation and peace facilitation efforts were restricted to the DRC, focusing on the current election process.

He also reported on the status of SADCBRIG, noting that its establishment was at an advanced stage. All SADC member countries have 'officially pledged' standby military and police units, and the RPTC was also "fully functional albeit with scanty resources". In his view, the RPTC would serve as a hub for the dissemination of expertise in peace support capabilities "by creating strategic partnerships with a myriad of specialised research institutions abound within and beyond the region."

Finally, the role of civil society in the implementation of the SIPO featured prominently in the acting Director's overview. He made the general point that "civil society plays a critical role in ensuring intra-regional confidence building and the promotion of the culture of peace and democratic values" (Ndlovu, 2006: 13) and identified the development of a SADC-Civil Society Partnership as an example of a mechanism for conflict prevention. He also envisaged a role for civil society in the activities of the REWC, but was silent on the civilian dimensions of the SADCBRIG.

\section{What does it all mean?}

There is no question that SADC, through its newly-established Organ (including the SIPO), has made progress. The Organ Directorate can rightly claim that the region experiences relative peace and security (although not entirely because of the Organ!) and that the focus should be on responding to the human security agenda. From the Organ Directorate's perspective, these issues have been identified as in need of further operationalisation.

Yet in reviewing the status of the SIPO there are also some worrying signals. The first, and most obvious one, relates to the ongoing signals from the 
Directorate which leads to perceptions of secrecy and unaccountability as far as the Organ and its Directorate are concerned. ICPs and civil society members alike register frustration, on a regular basis, at the lack of engagement with the Organ and Directorate. Secondly, although the focus (in the SIPO and the Organ Directorate) seems to be firmly on meeting the region's human security challenges, there appears to be an obsession with the SADCBRIG. As analysts have pointed out elsewhere, it is a military obsession, whereby the AU request for standby arrangements is interpreted as needing a militarist response, leaving behind civilian input and participation, if not deleted from planning altogether. Hence, the questions of deployment mandate, decision making, and training remain pertinent. But more broadly, these operational questions relate to the issue of what kind of security SADC believes it ought to supply. It is not easy to determine the thinking of the Organ leadership in this regard. The policy templates which guide the creation of SADCBRIG is fairly clear on this: support is to be given to UN-mandated peace missions, and military intervention is needed in cases of crimes against humanity, gross violations of human rights, genocide and the like. In SADC, the thinking around support / intervention criteria seemingly has not yet been consolidated (Macaringue, 2006: 5). Perhaps this is not surprising, as the global debate over the operationalisation of the principle to protect citizens from state abuse shows. Darfur graphically illustrates that neither the UN, nor the AU are clear about objectives or ready and prepared to carry out such an intervention. In the case of SADC much additional preparatory work lies ahead prior to SADCBRIG being deployed in an enforcement manner.

In order for the SIPO and its managers to move beyond some of this criticism, it is suggested that the proposed SADC-Civil Society Partnerships, as identified by the acting Director of Politics, Defence and Security during the SADC Consultative Conference of 2006, be activated expeditiously. Apart from establishing a much-needed channel of communication, such structured engagements will allow both sides to pursue matters in a manner that will benefit the broader integration project. Over and above such confidence-building measures, it will also provide ICPs an additional channel to engage with the Organ.

On a another level, and following from the argument that one ought not to expect the Organ Directorate to lead with political decision-making in the areas of politics, defence and security, it is recommended that individual member countries examine their own approach and commitment to the Organ's objectives. Which of the three scenarios are attractive to members? To determine, some questions can be put to the nation: Does the regional integration project, and the pursuance of peace and stability, resonate with its own broad vision of the future? Does the country get an adequate return on its investment in SADC? Is committing to SADC (in terms of human and physical resources) in the national interest? Critically, how do the regional peace and security policy frameworks integrate with domestic policies? What is the view of SADC amongst the general public? Is there a regular review of the regional/national interface? As with the AU peer review process, these questions ought not to be answered by government and state managers alone: civil society has 
a critical role to play. One has to gather responses to these kinds of questions from the thirteen/fourteen member states in order to determine whether SADC is really being held together by common values and norms - and is transiting from the regime security paradigm to the human security paradigm such that it resembles a truly regional, democratic integration project.

For those supportive of the vision, more work is to be done in preparing for the further prioritisation and implementation of the SIPO, taking into account the specificities of the parts which make up the whole. On this basis the SIPO can then be reformulated to look like the road map it was supposed to be in the first place. The 2006 Summit in Maseru seems to point the way forward: it has finally accepted a road map to realise the Community's vision of deeper regional integration and poverty eradication by specifying stages and timelines: from a Free Trade Area in 2008, to a Customs Union in 2010, to a Common Market in 2015 and a Monetary Union by 2016 (SADC, 2006).

In conclusion, the article's brief affaire with New Institutionalism allowed the construction of a view of SADC security co-operation (Box 1) which suggests a developmental path from informal, ad hoc to formal, rules-based governance. Which factors motivate and encourage, or discourage and retard such co-operation, how can such behaviour be examined, what is the nature of relations between players, including power dynamics between strong and weak - these are illustrative of the research agenda emerging from such a perspective. Lowndes' scheme (Box 2) might assist in determining where or how SADC and its security co-operation fit. This appears to be good news. Surely this provides a critical anchor for the broader integration project? After all, institutions (should) provide a certain rationality, certainty and regularity to political processes. Yet many questions remain. As we have noted above, the promotors of the security community concept set strict criteria in order for a regional institution to be allowed into such a club of the caring. For some, SADC does not (or even more severe, cannot) qualify for such membership. And therefore, the New Institutionalist paradigm fails to inspire as a mechanism to move the region out of the poverty trap, or as a compass to improve institutional and functional co-operation in the SADC region. However, for epistemological reasons the paradigm also suffers. It wants to assume that collectives (or its rulers) tend to act rationally, but as our experience tells us, this is often untrue. In the case of SADC it becomes a dangerous assumption, in need of deconstruction, led for example by critical theorists who ask about interests behind the regional security project, its drivers, and the nature of their behaviour.

By attempting to explore a new avenue for understanding security cooperation in SADC, through the insights of the New Institutionalism, the article found that the SADC leadership are rhetorically committed to full integration in both the socio-economic and security arenas (and to the eventual merging of the two into one, human security, agenda). Yet, the practice reveals the maintenance of a stable (but not efficient) institution, used by members to behave in a disaggregated manner, driven by the overriding demands of national interest and sovereignty. It is unclear, 
at this time, whether this state-driven project of selective co-operation might lead to deeper, more meaningful forms of co-operation and integration, in a manner that will give expression to the true meaning of human security: to be free from want, and free from fear.

\section{References}

Booth, K and P Vale (1995) 'Security in southern Africa: After apartheid, beyond realism', International Affairs, vol 71(2).

Cawthra, G and A van Nieuwkerk (2004) 'Regional renaissance? Security in a globalised world: The Southern African Development Community', FES Occasional Paper, Bonn: Friedrich Ebert Foundation.

Fisher, L and N Ngoma (2005) 'The SADC Organ: Challenges in the new millennium', ISS Occasional Paper 114, August.

Hansohm, D et al (2005) 'Conclusion: Progress towards integration in Southern Africa in 2004-2005', in Hansohm, D et al, Monitoring regional integration in Southern Africa Yearbook, vol 5, Windhoek: NEPRU.

Isaksen, J and E Tjønneland (2001) Assessing the restructuring of SADC: Positions, policies and progress, A report commissioned by the Norwegian Agency for Development Cooperation (NORAD), December.

Lambrechts, K (2001) 'The SADC's origins', in De Villiers, R and K Lambrechts (eds.), The IGD guide to the Southern African Development Community, Braamfontein: Institute for Global Dialogue.

Landsberg, C and M Baregu (2005) 'Introduction', in Baregu, M and C Landsberg (eds.), From Cape to Congo. Southern Africa's evolving security challenges, Boulder: Lynne Rienner.

Le Pere, G and E Tjønneland (2005) 'Which way SADC? Advancing co-operation and integration in Southern Africa', Institute for Global Dialogue Occasional Paper, no 51.

Lowndes, V (1996) 'Varieties of new institutionalism: A critical appraisal', Public Administration, vol 74, Summer.

Macaringue, P (2006) The military dimension of security co-operation in SADC, Paper delivered at the Formative Process Research on Integration in Southern Africa (FOPRISA) annual conference, November 2006, Maputo.

Makoa, F (2005) 'Managing conflict in an integrating Southern Africa: Peace, security and stability in lieu of democracy?', in Hansohm, D et al, Monitoring regional integration in Southern Africa Yearbook, vol 5, Windhoek: NEPRU.

Mandaza, I and A Tostensen (1994) Southern Africa in search of a common future: From the Conference to the Community, Gaborone: SADC.

Mulaudzi, C (2006) 'The politics of regionalism in Southern Africa', Institute for Global Dialogue Occasional Paper, no 51. 
Nathan, L (2004) 'The absence of common values and failure of common security in Southern Africa, 1992-2003', Crisis States Programme Working Paper Series, no 1, London: Development Research Centre.

Ndlovu, J (2006) 'New SADC-ICP partnership for the implementation of the SIPO', Briefing note delivered at the SADC Consultative Conference, 27 April 2006, Windhoek.

Ngoma, N (2005) Prospects for a security community in Southern Africa, Pretoria: Institute for Security Studies.

Omari, A (2000) The rise and decline of the Frontline States of Southern Africa: 1975-1990, Unpublished PhD thesis, University of Dalhousie, Canada.

Oosthuizen, G (2006) The Southern African Development Community: The organisation, its policies and prospects, Midrand: Institute for Global Dialogue.

Parsons, W (1995) Public policy. An introduction to the theory and practice of policy analysis, Cheltenham: Edward Elgar.

Powell, W and P DiMaggio (eds.) (1991) The new institutionalism in organisational analysis, Chicago: The University of Chicago Press.

Schoeman, M (1998) 'An exploration of the link between security and development' in Solomon, H and M Schoeman (eds.), Security, development and gender in Africa, Pretoria: Institute for Security Studies.

Smith, ME (2004) Europe's foreign and security policy: The institutionalisation of cooperation, Cambridge University Press.

Tjønneland, E (2005) 'Making SADC work? Revisiting institutional reform', in Hansohm, D et al, Monitoring regional integration in Southern Africa Yearbook, vol 5, Windhoek: NEPRU.

Van Nieuwkerk, A (1999) 'Promoting peace and security in Southern Africa: Is SADC the appropriate vehicle?', Global Dialogue, vol 4(3), December.

Van Nieuwkerk, A (2003) 'Promoting collective security in Africa: The role of the African Union and the New Partnership for Africa's Development', in Field, S, Towards a collaborative security regime for Africa, Johannesburg: Institute for Global Dialogue.

Van Zyl Slabbert, F (2006) The other side of history, Johannesburg: Jonthan Ball.

Williams, R (2001) 'Managing regional security', in De Villiers, R and K Lambrechts (eds.), The IGD guide to the Southern African Development Community, Braamfontein: Institute for Global Dialogue.

Zacharias, A (2003) 'Redefining security', in Baregu, M and C Landsberg (eds.), From Cape to Congo. Southern Africa's evolving security challenges, Boulder: Lynne Rienner.

Various African policy frameworks, accessible at www.saferafrica.org. 


\section{Endnotes}

${ }^{1}$ An earlier version of this article was presented during the South African Association of Political Studies (SAAPS) Conference at the University of the Western Cape, 5-8 September 2006.

${ }^{2}$ The assistance of André du Pisani and Paulino Macaringue in deepening our understanding of some of the intricate dynamics at play in the southern African security sector is appreciated. The contributions of two anonymous referees are also acknowledged. However the author remains responsible for the paper's arguments and conclusions.

${ }^{3}$ See for example the September 2004 edition of Security Dialogue, in which a special section provided a broad overview of human security debates ten years after the popularisation of the concept by the United Nations Development Programme.

${ }^{4}$ One such analyst remarked that "colonialism, Cold War, liberation wars and anti-racial discrimination are regarded as part of the political vocabulary of the entire SADC region" (Macaringue, 2006).

${ }^{5}$ See the 'Policy Framework for the Establishment of the African Standby Force and the Military Staff Committee (Part 1)' as adopted by the African Chiefs of Defence Staff in May 2003 and revised in January 2004. Available online at www.saferafrica.org.

${ }^{6}$ See Art 13 (3) of the 'Protocol relating to the Establishment of the Peace and Security Council of the African Union' as adopted in July 2002 and entered into force in December 2003. Available online at www.africa-union.org.

${ }^{7}$ According to SIPO its scope includes the following issues:

\section{In the political sector:}

- $\quad$ To protect the people and safeguard the region against domestic instability;

- $\quad$ Promote the evolution of common political values and institutions;

- $\quad$ Prevent, contain and resolve conflict by peaceful means;

- $\quad$ Promote democracy and human rights;

- $\quad$ Observe and encourage states to implement the UN Charter and the AU Constitutive Act;

- $\quad$ Develop peacekeeping capacity of national defence forces;

- Enhance regional capacity re disaster management and co-ordination of international humanitarian assistance;

- Develop a common foreign policy approach on issues of mutual concern.

\section{The defence sector:}

- $\quad$ To protect the people and safeguard the region against domestic instability;

- $\quad$ Promote regional co-operation on matters related to security and defence;

- $\quad$ Consider enforcement action as a matter of last resort;

- $\quad$ Consider the development of a collective security capacity and conclude a mutual defence pact to respond to external military threats;

- $\quad$ To observe conventions and treaties on arms control and disarmament;

- $\quad$ To develop peacekeeping capacity;

- $\quad$ To enhance regional capacity re disaster management and co-ordination of international humanitarian assistance.

The state security sector (intelligence services): Promote regional co-operation on matters related to security and defence;

- $\quad$ Prevent, contain and resolve conflict by peaceful means;

- $\quad$ Consider the development of a collective security capacity and conclude a mutual defence pact to respond to external military threats;

- Develop close co-operation between the police and state security services. 


\section{The public security sector (law enforcement agencies):}

- $\quad$ To protect the people and safeguard the region against domestic instability;

- $\quad$ Promote regional co-operation on matters related to security and defence;

- $\quad$ Consider enforcement action as a matter of last resort;

- $\quad$ Promote democracy and human rights;

- $\quad$ Develop close co-operation between the state security and defence forces;

- $\quad$ To observe conventions and treaties on arms control and disarmament;

- To develop peacekeeping capacity;

- $\quad$ To enhance regional capacity re disaster management and co-ordination of international humanitarian assistance.

${ }^{8}$ A UNDP-funded conference scheduled for senior security sector officials from SADC in December 2004 in Maputo rejected proposals for the urgent implementation of a range of SIPO objectives. By observing proceedings, it became clear that SADC members did not share a common understanding or vision of the Organ or its activities. The formal communique, produced by the Organ Directorate, steered clear from revealing these underlying tensions.

${ }^{9}$ Referring to Haroon Rashid Aswat, a Lusaka resident wanted for questioning in relation to the London bomb attacks of 7 July 2005. 